\title{
Impact of Micro Finance on Household Expenditure Pattern of Rural Women Borrowers: An Empirical Analysis
}

\author{
Vikas Batra1, Pooja Yadav ${ }^{1 *}$ and Ashish Kumar² \\ ${ }^{1}$ Department of Economics, Indira Gandhi University, Meerpur, Rewari-Haryana, India \\ ${ }^{2}$ University School of Management Studies, Guru Gobind Singh Indraprastha University, New Delhi, India
}

*Corresponding author: poojayrao534@gmail.com

Received: 24-01-2020

Revised: $18-04-2020$

Accepted: 27-05-2020

\begin{abstract}
The present study elaborates the performance of SHG-Bank linkage programme of NABARD in Rajasthan. It mainly discusses the impact of SHGs on education, food and health expenditure by households. The study found that SHGs have helped the members to meet out household expenditure on food, health and education. The expenditure pattern shows that majority of households have contributed to the expenditure from the income earned after becoming the member of group. The qualitative analysis with the help of two case studies of rural women further validates the quantitative analysis and claimed that because of the involvement in self help groups, the income and expenditure level increased along with standard of living. The study suggests that sustained efforts should be continued to promote various livelihood generation activities so that the household may increase their income and put more household expenditure on food, health and education. Apart from this, the members should be provided proper orientation to utilise the money in most efficient manner.
\end{abstract}

Keywords: Self-help groups, expenditure, health, education, food

Microfinance is a provision of providing loans and other financial services to the poor people. It is confirmed from various studies that microfinance programmes have made positive impact on income level and expenditure capacities of the group members. It helps the institutions to reduce poverty level in under developing countries and India (Kundu et al. 2013). In South Asia, the micro-credit was first introduced in Bangladesh by Mohammed Yunus thorough Grameen Bank in 1976. In India, the microfinance is driven by selfhelp group model. A Self-help group is an association of 10 to 20 members for common objectives such as credit, savings to start a livelihood activities and overall development. The members of SHGs pools their small saving regulate a fixed amount on mainly on monthly or weekly basis and provide loan to members. The social and economic homogeneity helps the group members to achieve desired targets. It has been found that women's groups perform better then the men's group and mixed groups. In India, the SHG-Bank Linkage Programme was started by the National Bank for Agriculture and Rural Development in 1992 and it acts as apex body for financial inclusion among rural poor through creating linkage of self-help groups with the banks. With the participation of various NGOs, bankers, other formal and informal organizations and direct or indirect involvement of government functionaries, NABARD is instrumental for training and capacity building of all stakeholders. The SBLP has become a significant model in terms of both numbers disbursed and loan 
outstanding (Tankha 2012). In this way, NABARD has been playing the role of propagator and facilitator for self help groups in the country (Somashekhar, 2015) SHG programme has been playing a vital role to encourage microfinance in India as microfinance has been considered a powerful instrument to enhance income and expenditure level of members, reducing vulnerabilities and thus empowering rural women.

\section{Progress of SHG-Bank Linkage Programme in Rajasthan}

Geographically, Rajasthan is a largest state of the country and majority of population of this state is generally depends on primary sector for their livelihoods. Rajasthan has registered a remarkable progress under Linkage Programme. Development of Women and Child Development (DWCD) is key organization in promoting SHGs in Rajasthan. Agencies like rural development department, integrated child development schemes and other microfinance institutions along with NGOs are also active in the state for the promotion of microfinance. The numbers of SHGs linked with banks were 2,10,436 in the year 2007-08 and continued to increase till 2011-12. There was a slight decline till 201617 but in the year 2017-18, it started to increase. In the state, the cumulative numbers of SHGs were in 201718. The amount of outstanding loan of SHGs with banks also increased ₹ 28899.79 lakhs in 2007-08 to ₹ 631222.24 lakhs in the year of 2017-18 (Table 1).

Table 1: Progress of SHG-bank Linkage Programme in Rajasthan (Loan Outstanding in lakhs)

\begin{tabular}{lllll}
\hline & \multicolumn{2}{c}{ No. of SHGs } & \multicolumn{2}{c}{ Loan Amount } \\
Year & $\begin{array}{l}\text { During the } \\
\text { Year }\end{array}$ & Cumulative & $\begin{array}{l}\text { During the } \\
\text { Year }\end{array}$ & Cumulative \\
\hline $2007-08$ & 72599 & 210436 & 25004.45 & 28899.79 \\
$2008-09$ & 97957 & 308393 & 36654.63 & 65554.42 \\
$2009-10$ & 96206 & 404599 & 46328.65 & 111883.07 \\
$2010-11$ & 90393 & 494992 & 44540.04 & 156423.11 \\
$2011-12$ & 134961 & 629953 & 71490.25 & 227913.36 \\
$2012-13$ & 129571 & 759524 & 63294.45 & 291207.81 \\
$2013-14$ & 129830 & 889354 & 64229.04 & 355436.85 \\
$2014-15$ & 119607 & 1008961 & 108019.05 & 463455.90
\end{tabular}

\begin{tabular}{lllll}
$2015-16$ & 98107 & 1107068 & 65183.06 & 528638.96 \\
$2016-17$ & 86484 & 1193552 & 52954.25 & 581593.21 \\
$2017-18$ & 99286 & 1292838 & 49689.03 & 631222.24 \\
\hline
\end{tabular}

Source: Status of Microfinance in India, various years.

\section{Agency Wise Distribution of SHGs in Rajasthan}

The agency-wise details of SHGs linked with banks and a loan disbursed to SHGs during the year 200708 to 2017-18 is given in Table 2. In the state, as on 31 March 2008, the share of co-operative banks was 53.09\% with 11622 SHGs followed by commercial bank (41.6\%) and Regional Rural Banks (5.31\%). In the recent years, commercial banks' share has been increased and share of Regional Rural Banks are also increased. In Rajasthan, Co-operative banks are on declining side in the financing the self-help groups.

Table 2: Agency Wise Distribution of SHGs in Rajasthan (Loan Disbursed)

\begin{tabular}{|c|c|c|c|c|c|c|}
\hline \multirow{2}{*}{ Year } & \multicolumn{2}{|c|}{$\begin{array}{c}\text { Commercial } \\
\text { bank }\end{array}$} & \multicolumn{2}{|c|}{$\begin{array}{c}\text { Regional Rural } \\
\text { Bank }\end{array}$} & \multicolumn{2}{|c|}{$\begin{array}{c}\text { Cooperative } \\
\text { Bank }\end{array}$} \\
\hline & $\begin{array}{l}\text { No. of } \\
\text { SHG }\end{array}$ & $\begin{array}{l}\text { Bank } \\
\text { Loan }\end{array}$ & $\begin{array}{l}\text { No. of } \\
\text { SHG }\end{array}$ & $\begin{array}{l}\text { Bank } \\
\text { Loan }\end{array}$ & $\begin{array}{l}\text { No. of } \\
\text { SHG }\end{array}$ & $\begin{array}{l}\text { Bank } \\
\text { Loan }\end{array}$ \\
\hline 2007-08 & 9106 & 5291.89 & 1163 & 384.35 & 11622 & 4492.11 \\
\hline 2008-09 & 9597 & 7697.98 & 8843 & 3912.22 & 11247 & 5123.93 \\
\hline 2009-10 & 9120 & 8695.74 & 8747 & 5460.29 & 8807 & 5016.22 \\
\hline 2010-11 & 8427 & 5975.72 & 7977 & 5544.21 & 12319 & 8295.36 \\
\hline 2011-12 & 4323 & 6789.74 & 7752 & 6053.51 & 6787 & 5430.12 \\
\hline 2012-13 & 8634 & 11017.04 & 5360 & 4702.89 & 6167 & 5368.45 \\
\hline 2013-14 & 8737 & 11701.00 & 2830 & 3002.69 & 5840 & 4756.11 \\
\hline 2014-15 & 11538 & 19887.52 & 3735 & 2744.18 & 17317 & 6289.10 \\
\hline 2015-16 & 12932 & 23139.12 & 3816 & 2841.57 & 8562 & 6196.50 \\
\hline 2016-17 & 18109 & 27200.33 & 12472 & 11647.34 & 1619 & 1803.09 \\
\hline 2017-18 & 19086 & 22926.65 & 9790 & 8239.01 & 1286 & 1428.30 \\
\hline
\end{tabular}

Source: Status of Microfinance in India, various years.

\section{Non Performing Assets for Bank Loans to SHGs in Rajasthan}

High level of non-performing asset always posed hindrance for the financial institutions. The table 3 shows the amount of gross non-performing asset against SHGBank Linkage in Rajasthan in the last 10 years. It shows that the amount of NPAs increased continuously from 
2008 to 2018. The data shows the percentage growth of NPAs from increased $8.6 \%$ in 2009 to $22.97 \%$ in 2018.

Table 3: NPAs for Bank Loans to SHGs and Recovery performance in Rajasthan

\begin{tabular}{lll}
\hline Year & $\begin{array}{l}\text { Amount of gross NPAs } \\
\text { against SHGs }\end{array}$ & $\begin{array}{l}\text { NPAs as Percentage to } \\
\text { Loan Outstanding }\end{array}$ \\
\hline $2008-09$ & 2995.33 & 8.60 \\
$2009-10$ & 3750.63 & 8.10 \\
$2010-11$ & 3780.87 & 8.49 \\
$2011-12$ & 4636.33 & 6.49 \\
$2012-13$ & 7563.40 & 11.95 \\
$2013-14$ & 7829.36 & 12.19 \\
$2015-16$ & 16348.70 & 25.08 \\
$2016-17$ & 13427.16 & 25.36 \\
$2017-18$ & 11414.53 & 22.97 \\
\hline
\end{tabular}

Source: Status of Microfinance in India, various years.

\section{REVIEW OF LITERATURE}

Holvoet (2004) in his study in south India examined the impact of microfinance on schooling and literacy. While investigating the Integrated Rural Development Programme and Tamilnadu Women's Development Programme, the logistic regression analysis found that direct individual lending system has no significant impact on education. In case of group lending, it strongly affects the school education particularly for girls in the study area. The study suggest that efforts should be made to enhance women's capacity in intra-household decision making so that they can put more attentions on girls education.

Sooryamoorthy (2007) examined the loan use patterns of 1116 members of 60 groups in Allapuzha and Ernakulum districts of Kerala. The study found that majority of the members utilized the micro loans mainly for immediate consumption requirements rather than putting more investment for enterprise development. Smaller amount was put on education and health related issues in the family. Very few members invested the amount on self employment microenterprise. The study emphasized on the use of loan for enterprise development for extra income that may help the members to meet out their consumption requirements on sustained basis.
Patel (2014) examined the impact of microfinance on household expenditure pattern in Kutch district of Gujarat. The study found that the expenditure pattern was very much correlated with the level of income. The increased income helped the members to enhance their expenditure level and standard of living also. The study also mentioned that the member were less satisfactory with these changes of expenditure on health and education.

Shajahan et al. (2015) evaluated the household expenditure pattern of rural women in Bangladesh and compared the impact of government and nongovernment organizations on the expenditure pattern and living standard of the respondents. The study found that the microcredit was a powerful tool and it helped significantly to increase the level of income and also improved expenditureon food and non-food expenditure including health and, education. Furthermore, the study the level of income of the members of both governmental and non-governmental organisations was almost same but members of government organization put more amount on expenditure.

Parajuli (2016) highlighted the impact of microfinance services on household expenditure pattern in Nepal. It draws on primary empirical data gathered by interviewing 400 respondents in the Kathmandu, Lalitpur and Sindhupalchok. The study observed that the household expenditure and quality of product was highly affected by the credit facilities and level of income. The study recommends that to MFIs should provide regular training to enhance income level so that they can put more amounts on expenditure.

Maity (2016) in his study of Medinipur district of West Bengal, described that microfinance has helped the women to increase the expenditure on health, education and other family needs. The percentage expenditure was more in case of high income group members than low income members.

Sharma (2017) evaluated the status of microfinance in Rajasthan and focus on SHG-Bank linkage model. The study found that the SHG- bank linkage model has emerged as a leading and widely recognized model. This study described that the SHGs movement in Rajasthan 
was helpful to increase the income levels of their members. It further helped to reduce the dependency on local money lenders and increased spending on the education of their children and health.

Vishwanath (2018) made an analysis on the impact of micro credit services on education expenditure in Kerala. The study was conducted on two micro finance institutions working in the state. There was no direct association between micro credit and access to education but wealth and status of family played an important role. Access to micro credit helped the borrowers to put more investment in education of children.

Kumari (2018) studied the impact of women self-help groups on household food consumption pattern in Saharsa district of Bihar. The studies revealed that majority of members were engaged in various income generation activities. It was found that loan amount positively affected their household consption pattern.

Sushila, et al. (2019) in her study in Dungarpur district of Rajasthan described the effectiveness of women Self Help Groups on the level income, expenditure and savings. The study was based on empirical survey data of 96 members from four blocks of Dungarpur district during 2016-17. It was observed that various income generating activities were undertaken by the members after becoming members. The study found that groups have a positive impact on monthly income, household expenditure and savings of members.

\section{OBJECTIVES, SURVEY DESIGN AND RESEARCH METHODOLOGY}

The specific objectives of the study are to examine the performance of SHG Bank linkage programme in Rajasthan in terms of the impact on food, education and health expenditure The study is empirical in nature and based on primary and as well as secondary data. The secondary data was collected from annual reports of NABARD and report on status of microfinance in India. Primary survey was undertaken in Alwar district of Rajasthan in four blocks are Allawara, Bansur, Kishangarh, and Mundawar. A sample of 100 female members was taken from 25 self-help groups which were promoted under NABARD SHG-Bank Linkage Programme. Apart from simple statistical analysis, case study method was also used in the study. The Sampling Process was taken as follow:

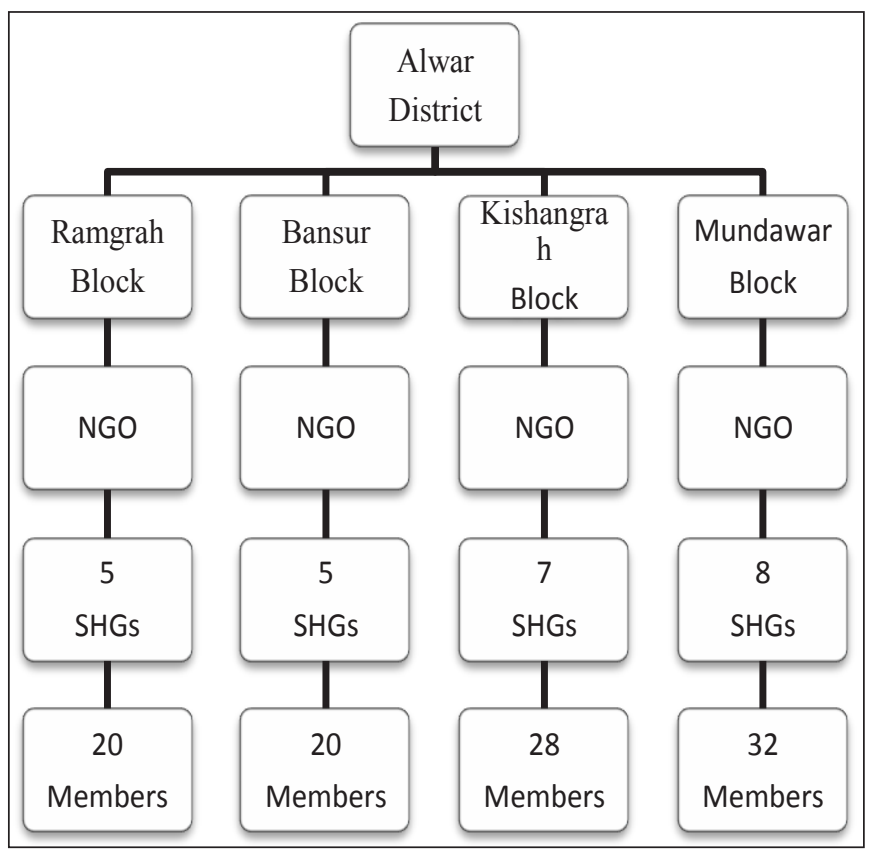

Fig. 1: Sampling Process followed in the Study

\section{RESULTS AND DISCUSSION}

\section{General Information about the respondents}

Table 4 shows that the distribution of the respondent according to their caste and religion. In the study sample, 91 percent respondents were Hindu followed by Sikhs and Muslim. It has been observed that nearly half of the respondents (49 percent) belong to the Schedule Caste category followed by Other Backward Class with the 27 percent. A total of 24 percent respondents belong to general category. According to the survey 39 percent respondent were landless, mainly those persons who belongs to the SC Category. However, 32 percent respondents who have their own land less than one or around one Acre agricultural land, nearly 25 percent members have land between 2 to 5 Acres and with the very small amount only 4 percent respondent have around 6 to 10 Acres land. 
Table 4: Information Regarding Religion, Caste and Land Holding

\begin{tabular}{lll}
\hline General information & Sub Category & No of Respondents \\
\hline Religion & Hindu & 91 \\
& Muslim & 1 \\
& Sikh & 8 \\
& Total & 100 \\
\hline Caste & Gen. & 24 \\
& S.C & 49 \\
& O.B.C & 27 \\
& Total & 100 \\
\hline Agricultural land & Yes & 61 \\
& No & 39 \\
\hline Size of land Holding & Less than 1 Acre & 32 \\
& 2 to 5 Acre & 25 \\
& 6 to 10 Acre & 4 \\
& Above 10 Acre & 0 \\
\hline
\end{tabular}

Source: Computed from Field Survey.

\section{Expenditure on Food, Health and Education after joining SHG}

Table 5 describes the impact of SHG-Bank Linkage Programme on expenditure food, health and education. The study shows that all members were able to purchase the more food items after joining the group. A total of 92 percent respondents used income to purchase the food items and 6 percent from both loan and income and only 2 percent used their loan amount. According to the survey, 89 percent respondents were able to approach the doctor easily after join the group. Further, 78 percent of them used their income for health purpose and 9 percent of used loan amount. It was found that 13 percent respondent used both income and loan for this purpose.

Moreover, 86 percent respondent said that they were able to put more expenditure on the education of their children after joining the group and majority of them were able to do so because of high income level. Thus, it is important to highlight that SHGs not only increased the income of the group members but also improved their standard of living in terms of household expenditure.
Table 5: Expenditure on Food, Health and Education after joining SHG

\begin{tabular}{|c|c|c|}
\hline Particulars & Sub Categories & Number \\
\hline $\begin{array}{l}\text { Do you now able to purchase } \\
\text { more food items }\end{array}$ & Yes & 100 \\
\hline \multirow[t]{3}{*}{$\begin{array}{l}\text { How do you contribute in food } \\
\text { expenditure }\end{array}$} & $\begin{array}{l}\text { Income earned } \\
\text { from IGA }\end{array}$ & 92 \\
\hline & Loan & 2 \\
\hline & Both & 6 \\
\hline \multirow{2}{*}{$\begin{array}{l}\text { Do you now able to easily } \\
\text { approach the Doctor in the case } \\
\text { of sickness }\end{array}$} & Yes & 89 \\
\hline & No & 11 \\
\hline \multirow{3}{*}{$\begin{array}{l}\text { Family contribution in the case of } \\
\text { sickness because of SHG }\end{array}$} & Large extent & 76 \\
\hline & Limited & 22 \\
\hline & Nil & 02 \\
\hline \multirow[t]{3}{*}{$\begin{array}{l}\text { How do you contribute in case of } \\
\text { health expenditure }\end{array}$} & $\begin{array}{l}\text { Income earned } \\
\text { from IGA }\end{array}$ & 78 \\
\hline & From loan & 09 \\
\hline & From both & 13 \\
\hline \multirow{2}{*}{$\begin{array}{l}\text { Do you now able to put more } \\
\text { expenditure on children } \\
\text { education }\end{array}$} & Yes & 86 \\
\hline & No & 14 \\
\hline \multirow{3}{*}{$\begin{array}{l}\text { Family contribution in the case of } \\
\text { expenditure because of } \mathrm{SHG}\end{array}$} & Large extent & 49 \\
\hline & Limited & 37 \\
\hline & Nil & 14 \\
\hline \multirow{3}{*}{$\begin{array}{l}\text { How do you contribute in the } \\
\text { expenditure on your children's } \\
\text { education }\end{array}$} & $\begin{array}{l}\text { Income earned } \\
\text { from IGA }\end{array}$ & 89 \\
\hline & From loan & 3 \\
\hline & From both & 8 \\
\hline
\end{tabular}

Source: Computed from Field Survey.

\section{IMPACT OF SELF HELP GROUPS ON EXPENDITURE LEVEL: A QUALITATIVE ANALYSIS}

The impact of self help groups on household expenditure especially on health, education and food was also analysed with the help of two successful case studies.

\section{Case Study-I}

Rajbala (changed name) is a 31 years old married woman from Doli-Bas village of Ramgarh block. She belongs to Scheduled Caste category. She was working as labourer before joining the self-help group. The earnings of her household were not sufficient to meet their family 
expenditure. When she joined the group, she was not that much satisfied. Later on, with the motivation by her husband, she came to know the uses of the amount and she purchased a buffalo. Now, she is earning around ₹ 4,000 per month from this activity. She got the loan four times from the bank under the supervision of local NGO. She also helped her husband to start a business through bank loan. After joining group, she has experienced that the expenditure on food, health, and child's education has increased. Now, she is completely satisfied as a member of her group. Her schedule of repayment of loan is very regular. Her decision-making power in the family is now improved.

\section{Case Study-II}

Kishori Devi (changed name) is a resident of village Macha in Kishangarh block of Alwar District. She is 43 years old and belongs to the Other Backward Class. She joined the group in the year 2011. She took the loan four times under NABARD- SHG-Bank Linkage Programme and also availed loan from the group. She used the first instalment of loan to repay the old debt and purchase a sewing machine and started tailoring. The second instalment of loan was used to construct new room. With her next bank loan, she opened cosmetic items shop. Now she is earning around ₹ 6,000 per month from her business. Kishori Devi also has claimed that because of increased income, the expenditure on food, health, and education to the children is also improved. In addition to this, she also claimed that dependency on the moneylender for loan has also reduced. She was very satisfied with in her group and also inspires other to join the same.

\section{CONCLUSION}

The study found that self help groups have positive impact on household level expenditure on health, education and food. In the majority of cases, it was found that income earned from livelihood activities was main factor in improving the household expenditure. The case studies mentioned in this paper also shows that microfinance has helped the group members to enhance their income and expenditure on health, education and food mainly because of income. The study suggests that sustained efforts should be continued with the involvement of all stakeholders to promote various livelihood generation activities so that the household may increase their capacities to put more household expenditure on food, health and education. Apart from this, the members should be provided proper orientation to utilise the money in most efficient manner.

\section{REFERENCES}

Chandran, K.P.V. and Sandhya, P. 2012. Progress of SHG-Bank Linkages in India: An Assessment of Key Issues, Economic Affairs, 57(3): 307-314.

Holvoet, Nathalie. 2004. Impact of Microfinance Programs on Children's Education: Do the Gender of the Borrower and the Delivery Model Matter? Journal of Microfinance / ESR Review, 6(2): 27-49.

Kumari V. 2018. Women Self-Help Group: A tool for Improving Decision Making in Agriculture Activities and Household Food Consumption Pattern, International Journal of Current Microbiology and Applied Sciences, Special Issue-7 pp. 3914-3922.

Kundu et al. 2013. Role of SHGs: A case study of Bardhman district of West Bengal, International Journal of Social Science, 2(1): 63-72.

Maity, Barnali 2016. Microfinance: Women from the margin to the mainstream, Journal of Rural Development, 35(1): 17-38.

NABARD. 2018. Status of Microfinance in India, Annual Reports, various years, retrieved from https://www.nabard.org/content. aspx?id=651

Parajuli. 2016. Impact of Microfinance on household expenditure: An Empirical study, IOSR Journal of Business and Management, 18(11) Ver. VII: 25-30.

Patel. 2014. The Impact of Microfinance on Household Expenditure Patterns: Evidence from Kutch (India), IOSR Journal of Economics and Finance, 5(6): 42-47.

Shajahan et al. 2015. The Impact of Microcredit on Household Expenditure Patterns of Rural Women Borrowers: A Comparative Study on Government Organization and Nongovernment Organization of Bangladesh, Conference Paper

Sharma, B. 2017. Status of Microfinance in Rajasthan: Problems and Prospectus, EPRA International Journal of Economic and Business Review, 5(7).

Somashekhar, K. 2015. Financial inclusion through self help groups for rural livelihoods-An analysis, International Journal of Social Science, 4(4): 289-296.

Sooryamoorthy, R. 2007. Microcredit for microenterprises or for immediate consumption needs, Sociological Bulletin, 56(3): 145157. 
Sushila, et al. 2019. Effectiveness of Women Self Help Groups (SHGs) Regarding Income, Saving and Expenditure, Indian Journal of Extension Education and Rural Development, 26: 96-98.

Tankha, Ajay. 2012. Banking on self-help groups-Twenty years on, Sage Publication India Pvt. Ltd.
Vishwanath, P.V. 2018. Microfinance and decision to invest in children's education, International Journal of Financial Studies, 6(16): 1-20. 
